\title{
Antiproliferative Activity of Extracts and Fractions from Irradiated Curcuma zanthorrhiza Rhizomes Against Mouse Leukemia and Human Cancer Cell Lines
}

\author{
E.K. Winarno ${ }^{*}$, H. Winarno and Susanto \\ Center for Isotopes and Radiation Application, National Nuclear Energy Agency, \\ Jl. Lebak Bulus Raya No. 49, Jakarta-12440, Indonesia
}

\section{ARTICLE INFO}

Article history:

Received 19 May 2019

Received in revised form 14 August 2019

Accepted 19 September 2019

Keywords:

Curcuma zanthorrhiza

Temulawak

Irradiation

Anticancer

Human cancer cell lines

\begin{abstract}
A B S T R A C T
Curcuma zanthorrhiza Roxb. is a medicinal plant that is used as a raw material in the herbal medicine and pharmaceutical industries. The main content of C. zanthorrhiza is curcuminoid, which is used as an antioxidant and an anticancer agent. The aim of this research was to study the effect of gamma radiation used for preserving simplicia or herbal drugs through the examination of their cytotoxicity against mouse leukemia L1210 cells and antiproliferative activity against human cancer cell lines HUT78, A549, HeLa, and THP1. The samples of curcuma rhizome were irradiated by gamma ray emitted by Cobalt-60 as a source at doses of 0 (control), 5, 7.5, 10, and $15 \mathrm{kGy}$. After irradiation, the samples were macerated using $n$-hexane, ethyl acetate, and ethanol, respectively. Preliminary cytotoxicity test toward extract from control sample against mouse leukemia L1210 cells revealed that the ethyl acetate extract was the most active extract inhibiting the growth of cells with an $\mathrm{IC}_{50}$ value of $16.6 \mu \mathrm{g} / \mathrm{mL}$, followed by ethanol extract $(18.8 \mu \mathrm{g} / \mathrm{mL})$ and $n$-hexane extract $(42.7 \mu \mathrm{g} / \mathrm{mL})$. Fractionation using a chromatography column of the ethyl acetate extract resulted in seven fractions denoted as F1-F7. The cytotoxicity test of the seven fractions against mouse leukemia L1210 cells showed that fraction $3(\mathrm{~F} 3)$ was the most active fraction with an $\mathrm{IC}_{50}$ value of $10.0 \mu \mathrm{g} / \mathrm{mL}$, followed by F7 $(11.2 \mu \mathrm{g} / \mathrm{mL}), \mathrm{F} 6(11.8 \mu \mathrm{g} / \mathrm{mL})$, F5 $(12.0 \mu \mathrm{g} / \mathrm{mL})$, F1 $(13.2 \mu \mathrm{g} / \mathrm{mL})$, F4 $(14.5 \mu \mathrm{g} / \mathrm{mL})$, and F2 $(27.8 \mu \mathrm{g} / \mathrm{mL})$, respectively. Based on these results, all irradiated samples were then extracted, fractionated, and tested for cytotoxicity in a similar manner. The result showed that irradiation of samples under doses up to $10 \mathrm{kGy}$ can be used to preserve Curcuma zanthorrhiza simplicia without damaging its efficacy. To ensure that the irradiation dose of $10 \mathrm{kGy}$ did not reduce anticancer activity, the F3 from the irradiated sample at a dose of $10 \mathrm{kGy}$ was also examined of its in-vitro antiproliferative activity using HUT78, A549, HeLa, and THP1 human cancer cell lines. The results showed that irradiation of the sample at a dose of $10 \mathrm{kGy}$ reduced the antiproliferative activity of F3 against HUT78 (32 \%), A549 (48 \%), HeLa (42 \%), and THP1 (31\%). However, its reduction did not eliminate its antiproliferative activities. These results indicated that the preservation of simplicia using radiation can be done at a maximum radiation dose of $10 \mathrm{kGy}$ by modifying the concentration of simplicia in the fabrication process of herbal medicine formulation.
\end{abstract}

(C) 2019 Atom Indonesia. All rights reserved

\section{INTRODUCTION}

Curcuma zanthorrhiza Roxb., known as Javanese turmeric (Indonesian: temulawak), is a member of the Zingiberaceae family that is one of the medicinal plant originating from Indonesia. It is

\footnotetext{
*Corresponding author.

E-mail address: erminkk@batan.go.id

DOI: https://doi.org/10.17146/aij.2019.957
}

commonly used as a herbal medicine for treating hepatitis and increasing body stamina [1,2]. Curcumin and desmethoxycurcumin are two of curcuminoid group compounds contained in ginger, turmeric, and other similar plants. Both of these compounds have benefits as antitumor, antioxidant, antiinflammatory, antimicrobial, antihyperlidemic, and hepatoprotector [3]. The European Medicines Agency [4] reported that $C$. zanthorrhiza rhizomes 
have been used in Europe since 1963, mainly to treat digestive, skin, and liver diseases and infections. The use of curcuma rhizomes has been continuously documented in European handbooks as a specific ingredient that meets the requirements of Directive 2004/24/EC for use as products that are classified as "Traditional Herbal Medicine Products". N.G. Vallianou et al. [5] stated that curcumin and its analogous compounds have been shown to have various anticancer properties in a series of tests on various cancer cells, such as pancreatic, lung, ovarian, oral, colorectal, and breast carcinoma cells, and melanoma cells. Z. Udin [6] reported that the cytotoxic activity test against YMB-1 cells toward standard xanthorrhizol compound and ethyl acetatesoluble portion from methanol extract showed an $\mathrm{IC}_{50}$ of 2.9 and $3.2 \mu \mathrm{g} / \mathrm{mL}$, respectively. A similar result was stated by S.F. Oon et al. [7] that xanthorrhizol extracted from $C$. xanthorrhiza shown the bioactivity in the form of anticancer, antimicrobial, antiinflammatory, antioxidant, antihyperglycemic, antihypertensive, antiplatelet, nephroprotective, hepatoprotective, estrogenic, and antiestrogenic effects. Riki et al. [8] stated that the curcuminoid extracted from curcuma proved to be able to inhibit HeLa cell growth by $93.3 \%$ at a concentration of $62.5 \mu \mathrm{g} / \mathrm{mL}$, while nanoparticle curcuminoid extract can increase its activity by $93.4 \%$ at the concentration of $2 \mu \mathrm{g} / \mathrm{mL}$. The study of the antiproliferative activity test of curcumin at a concentration of $20 \mu \mathrm{M}(\approx 7.4 \mu \mathrm{g} / \mathrm{mL})$ showed that the compound inhibited the growth of MCF-7 cancer cells [9].

Simplicia from Curcuma sp. as an ingredient for herbal medicine is easily overgrown by microbes. The quality of ingredients and herbal medicines itself must be free from contaminating pathogenic microbes. Irradiation technique is one of the methods for preserving agricultural products [10]. Gamma irradiation on $C$. zanthorrhiza rhizomes showed that the irradiation dose of $10 \mathrm{kGy}$ was sufficient to reduce microbes by 2-4 log cycles, while doses of up to $0.25 \mathrm{kGy}$ can inhibit the sprouting fresh of $C$. zanthorrhiza rhizomes [11]. Gamma irradiation doses of 3,5, and $7 \mathrm{kGy}$ did not affect the stability of curcuminoid structure from whole powder, powder-free essential oil, and crude extract of $C$. zanthorrhiza rhizome; thus, gamma irradiation can be used for pasteurization to improve the quality of $C$. zanthorrhiza rhizomes [11]. Another study showed that gamma irradiation of simplicia of Andrographis paniculata with irradiation doses of up to $7.5 \mathrm{kGy}$ did not eliminate its efficacy as an anticancer, and at that dose the irradiated simplicia did not show toxic properties in acute toxic examination toward male and female mice [12]. A study by E. Riswana et al. [13] showed that doses of 2.5-10 kGy were able to reduce microbial contamination from $10^{4}$ to $10^{1}$ colonies. E. Katrin et al. [14] suggested that ethanol extract from simplicia of $C$. zanthorrhiza irradiated at doses of 5 and $10 \mathrm{kGy}$ did not show toxic properties in acute toxicity examination toward female and male mice. This fact shows that gamma irradiations at doses of up to $10 \mathrm{kGy}$ for the purpose of disinfestation and extending the shelf life of an herbal drug and simplicia did not make the material toxic.

The aim of the research was to study the effect of gamma radiation on the anticancer efficacy of C. zanthorrhiza rhizomes preserved using gamma radiation by examining their cytotoxic activity against mouse leukemia L1210 cells and their antiproliferative activities on human cancer cells (HUT78, A549, HeLa, and THP1), and to study the chromatogram profile changes of thin layer chromatography.

\section{EXPERIMENTAL METHODS}

\section{Materials}

Curcuma zanthorrhiza Roxb. rhizomes obtained from PT. Sido Muncul (Herbal Medicine Industry), $n$-hexane p.a., ethyl acetate p.a., ethanol p.a., methanol p.a., RPMI 1640 medium (Gibco), bovine calf serum (Gibco), mouse leukemia L1210 cells originating from methylchlorantren-induced mice in DBA/2 strain obtained from the Institute of Physical and Chemical Research (RIKEN)-Japan, trypan blue, silica gel 60 with 70-230 mesh sizes (Merck), celite 545 (Merck), methanol HPLC grade (Prolabo), Fricke standard solution dosimeter for calibration of the radiation dose which consists of $0.001 \mathrm{M} \mathrm{Fe}\left(\mathrm{NH}_{4}\right)_{2} \cdot\left(\mathrm{SO}_{4}\right)_{2} \cdot 6 \mathrm{H}_{2} \mathrm{O}, 0.001 \mathrm{M} \mathrm{NaCl}$, and $0.4 \mathrm{M} \mathrm{H}_{2} \mathrm{SO}_{4}$.

\section{Equipment}

In this work, the equipment used consisted of the Natural Rubber Gamma Irradiator at CIRA with Cobalt-60 as a gamma radiation source, a $\mathrm{CO}_{2}$ incubator, an oven, an autoclave, a vacuum rotary evaporator (Buchi), UV lamps (254 nm wavelength), an electric heater, an ultrasonicator, an analytic balance, a chromatography column, a microscope (Nikon), glassware, multiwell tissue culture plates, and a hemocytometer.

\section{Preparation and irradiation of $C$. zanthorrhiza rhizomes}

The C. zanthorrhiza rhizomes were sliced, dried, and ground to a powder and then packed into ten polyethylene plastic bags containing $100 \mathrm{~g}$ 
each, then tightly sealed with a sealer machine. These materials were then irradiated in usual manner $[15,16]$ at varying doses, i.e., 5, 7.5, 10, and $15 \mathrm{kGy}$ (at a dose rate of $7.5 \mathrm{kGy} / \mathrm{h}$ ), and one set without irradiation as a control sample. Two bags were subjected to each radiation dose.

\section{Preparation of extracts and its cytotoxicity tests on mouse leukemia L1210 cells}

C. zanthorrhiza rhizomes (unirradiated and irradiated samples) were macerated with $n$-hexane, ethyl acetate, and ethanol, respectively $[15,16]$. Each maceration was done three times, and the obtained filtrate was then evaporated using rotary evaporator at a temperature of $\pm 40{ }^{\circ} \mathrm{C}$ under reduced pressure. The obtained extract was then dried under vacuum and weighed. The $n$-hexane, ethyl acetate, and ethanol extracts from an unirradiated sample (control sample) and from irradiated samples were tested for cytotoxicity on mouse leukemia L1210 cells. The concentration of the samples was varied as 5, $10,20,40$, and $80 \mu \mathrm{g} / \mathrm{mL}$ in methanol as described in the previous studies $[15,16]$. After incubation for $48 \mathrm{~h}$, the cell growth was calculated under a microscope on a $40 \times$ magnification by added trypan blue $[15,17]$. The extract is declared as active in inhibiting the growth of cancer cells or has cytotoxic activity if it has an $\mathrm{IC}_{50}$ value of $\leq 20 \mu \mathrm{g} / \mathrm{mL}$ $[9,15,16,18]$.

\section{Antiproliferative activity test of $\mathrm{F} 3$ against human cancer cell lines HUT78, A549, HeLa, and THP1}

To ensure that preservation of extracts using radiation did not significantly reduce their efficacy, the active fraction (F3) was tested for antiproliferative activity on human cancer lines according to the previous procedure as usual manner [18]. Samples were dissolved in dimethyl sulfoxide. Then, the DMEM F12 media was added to obtain concentrations of $2,4,8,16$, and $32 \mu \mathrm{g} / \mathrm{mL}$. After incubation for 72 hours, the numbers of living and dead cells were calculated. Subsequently, the $\mathrm{IC}_{50}$ value was calculated according to a previous procedure $[15,16,18]$.

\section{RESULTS AND DISCUSSION}

\section{Extraction}

The result of extraction by maceration for unirradiated $C$. zanthorrhiza rhizomes is presented in Table 1. From Table 1, it can be seen that the nonpolar compounds which are extracted into $n$-hexane provided yields ranging from 0.87 to $0.97 \%$, while semipolar components are extracted into ethyl acetate at yields of 4.4 to $6.3 \%$, and polar components were extracted into ethanol at 1.21-1.37\%, with total extracts ranging from 6.54 to $8.61 \%$. It is also seen that the higher the radiation dose the greater the tendency for extraction. Thus, it can be assumed that radiation treatment causes the component to be easily dissolved and extracted into the solvents. However, n-hexane extract from irradiated sample at a dose of $7.5 \mathrm{kGy}(0.87 \mathrm{~g})$ has a yield $6.5 \%$ lower than the average yield of $n$-hexane extract $(0.93 \mathrm{~g})$.

Table 1. The weight of n-hexane, ethyl acetate, and ethanol extracts from $100 \mathrm{~g}$ of $C$. zanthorrhiza rhizomes at varying irradiation doses; average of two replications.

\begin{tabular}{ccccc}
\hline $\begin{array}{c}\text { Dose } \\
(\mathrm{kGy})\end{array}$ & $\begin{array}{c}n \text {-hexane } \\
\text { extract }(\mathrm{g})\end{array}$ & $\begin{array}{c}\text { ethyl acetate } \\
\text { extract }(\mathrm{g})\end{array}$ & $\begin{array}{c}\text { ethanol } \\
\text { extract }(\mathrm{g})\end{array}$ & $\begin{array}{c}\text { Total extract } \\
(\mathrm{g} \text { or } \%)\end{array}$ \\
\hline $0 *$ & 0.92 & 4.41 & 1.21 & 6.54 \\
5 & 0.95 & 5.05 & 1.25 & 7.25 \\
7.5 & 0.87 & 5.77 & 1.27 & 7.91 \\
10 & 0.94 & 4.92 & 1.32 & 7.18 \\
15 & 0.97 & 6.27 & 1.37 & 8.61 \\
\hline
\end{tabular}

$* 0=$ un-irradiated sample $=$ control

\section{Cytotoxicity test of extracts on mouse leukemia L1210 cells}

In the preliminary screening of three extracts, namely $n$-hexane, ethyl acetate, and ethanol extracts, for cytotoxicity against mouse leukemia L1210 cells, the $\mathrm{IC}_{50}$ value of each extract was $42.7,16.6$, and $18.8 \mu \mathrm{g} / \mathrm{mL}$, respectively. Ethyl acetate and ethanol extracts are thus classified as potentially active as anticancer substances because they have $\mathrm{IC}_{50}<$ $20 \mu \mathrm{g} / \mathrm{mL}$, while $n$-hexane extract $(42.7 \mu \mathrm{g} / \mathrm{mL})$ is classified as a less-active extract $[9,15,16,18]$.

\section{Separation of ethyl acetate extract by column chromatography and cytotoxicity test on mouse leukemia L1210 cells}

The results of the separation from $1.0 \mathrm{~g}$ of ethyl acetate extracts from each unirradiated and irradiated samples consist of seven fractions (F1-F7), as shown in Table 2. From Table 2, it can be seen that the F3, F4, and F5 fractions had a higher yield than other fractions. It can be understood that a small amount of the more nonpolar components which are combined into F1 and F2 from the semipolar component (ethyl acetate extract) have been extracted first into the n-hexane solvent, while F6 and F7 contain a small amount of polar 
component which could be extracted into the ethyl acetate solvent.

Furthermore, all fractions of ethyl acetate extract from unirradiated samples were tested for cytotoxicity against mouse leukemia L1210 cells, and the results are presented in Fig. 1.

Table 2. Results of the column fractionation of ethyl acetate extract $(1.0 \mathrm{~g})$ for varying irradiation doses.

\begin{tabular}{cccccccc}
\hline $\begin{array}{c}\text { Dose } \\
(\mathrm{kGy})\end{array}$ & $\begin{array}{c}\mathrm{F} 1 \\
(\mathrm{mg})\end{array}$ & $\begin{array}{c}\mathrm{F} 2 \\
(\mathrm{mg})\end{array}$ & $\begin{array}{c}\mathrm{F} 3 \\
(\mathrm{mg})\end{array}$ & $\begin{array}{c}\mathrm{F} 4 \\
(\mathrm{mg})\end{array}$ & $\begin{array}{c}\mathrm{F} 5 \\
(\mathrm{mg})\end{array}$ & $\begin{array}{c}\mathrm{F} 6 \\
(\mathrm{mg})\end{array}$ & $\begin{array}{c}\mathrm{F} 7 \\
(\mathrm{mg})\end{array}$ \\
\hline $0^{*}$ & 126 & 13 & 227 & 258 & 159 & 71 & 129 \\
5 & 118 & 15 & 225 & 256 & 168 & 62 & 136 \\
7.5 & 114 & 14 & 204 & 285 & 172 & 71 & 130 \\
10 & 109 & 16 & 209 & 274 & 186 & 72 & 121 \\
15 & 73 & 15 & 212 & 283 & 162 & 79 & 137 \\
$* 0$
\end{tabular}

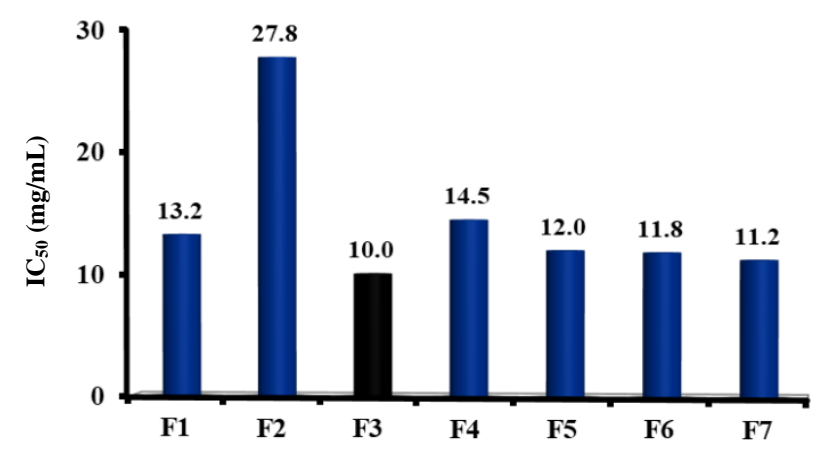

Fig. 1. Cytotoxicity of fractions F1-F7 from the ethyl acetate extract of unirradiated $C$. zanthorrhiza rhizomes against mouse leukemia L1210 cells.

It was seen that six fractions (F1, F3-F7) showed cytotoxicity with $\mathrm{IC}_{50}$ values $\leq 20 \mu \mathrm{g} / \mathrm{mL}$ $[9,15,16,18,19]$, whereas F2 was classified as a lessactive fraction with an $\mathrm{IC}_{50}$ value of $27.8 \mu \mathrm{g} / \mathrm{mL}$. Among those fractions, F3 is the most active fraction in inhibiting the growth of mouse leukemia L1210 cells with the smallest $\mathrm{IC}_{50}$ value $(10.0 \mu \mathrm{g} / \mathrm{mL})$. It was assumed that F3 contains curcumin compounds. The presence of curcumin compounds in F3 was evidenced by the thin layer chromatogram as shown in Fig. 2. On the other hand, F2 has the largest $\mathrm{IC}_{50}$ value, which means the lowest cytotoxic activity. This shows that most inactive components were accumulated in F2. Fortunately, F2 has the lowest yield for every irradiation dose.

Before spraying with cerium sulfate, F3 from all radiation doses only showed three spots (Fig. 2(a)), namely curcumin ( $\mathrm{Rf}=0.62)$, demethoxycurcumin $(\mathrm{Rf}=0.34)$, and bisdemethoxycurcumin $(\mathrm{Rf}=0.15)$ based on the authentic standard [20-23], but after spraying with cerium sulfate reagent and heating, the new spots appeared at $\mathrm{Rf}=0.52$ and $\mathrm{Rf}=0.28$ on $\mathrm{F} 3$ from irradiated samples at doses of $7.5,10$, and $15 \mathrm{kGy}$, although the spots were very thin (Fig. 2(b)). This fact indicates that gamma irradiation at doses of $\geq 7.5 \mathrm{kGy}$ can cause the formation of new compounds that are predicted as a result of degradation of the existing components.

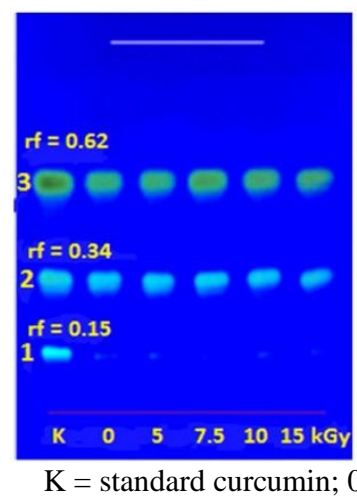

(a)

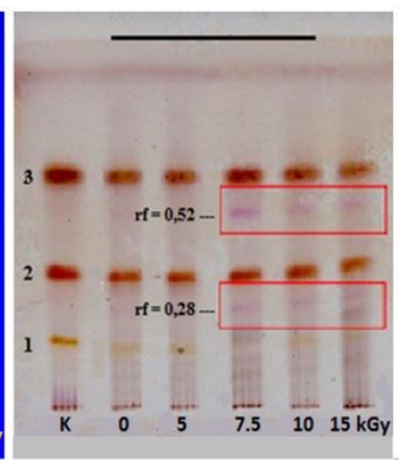

(b)
Fig. 2. Thin-layer chromatogram (TLC) of F3 from varying irradiation dose compared to the standard curcumin; (a) spots on the TLC plate under the UV lamp with $\lambda 366 \mathrm{~nm}$; (b) the TLC plate after spraying with reagent cerium sulfate and heating.

A study by Saefudin et al. [24] stated that curcumin from Curcuma zanthorrhiza had antitumor activities, with three mechanisms of tumor cell inhibition, namely: first, curcumin compound will replace the chromosomes in tumor cells to inhibits the binding $(3 \mathrm{H})$-uridine with tumor cells; second, curcumin inhibits binding the uridine into RNA; and third, curcumin inhibits binding the leucine into proteins during protein synthesis.

Based on Fig. 1, it can be stated that F3 is the most active fraction. For further determining the effect of radiation to the sample, all F3 from ethyl acetate extract of irradiated samples of each varying radiation dose were tested for cytotoxicity against mouse leukemia L1210 cells. The test results are presented in Fig. 3.

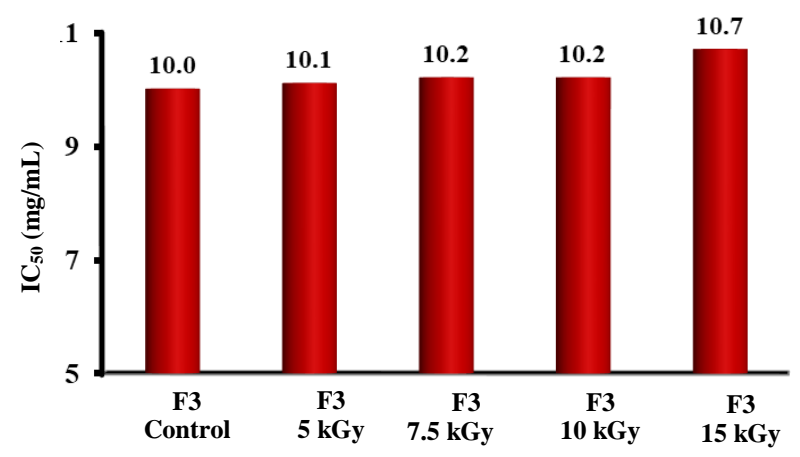

Fig. 3. Cytotoxicity against mouse leukemia L1210 cells of F3 from ethyl acetate extract of irradiated samples of each varying radiation dose.

From Fig. 3, it can be seen that there was an increase in $\mathrm{IC}_{50}$ value of $\mathrm{F} 3$ obtained from irradiated samples, but analysis using SPSS 24 ANOVA at $95 \%$ confidence level $(\alpha=0.05)$ showed that 
irradiation doses of up to $10 \mathrm{kGy}$ did not increase the $\mathrm{IC}_{50}$ value significantly or did not reduce the cytotoxicity against L1210 mouse leukemia cells. However, at a radiation dose of $15 \mathrm{kGy}$ there was a slight increase in $\mathrm{IC}_{50}$ value from 10.0 to $10.7 \mu \mathrm{g} / \mathrm{mL}$, it was significantly different based on the ANOVA test. In acute toxicity test carried out previously by E. Katrin et al. [14] showed that the irradiation of the sample at a dose of $10 \mathrm{kGy}$ did not make the sample acute-toxic.

Furthermore, based on the formation of new spots at $\mathrm{Rf}=0.28$ and $\mathrm{Rf}=0.52$ in thin layer chromatogram and the decreasing cytotoxicity of F3 at a dose of $15 \mathrm{kGy}$, it can be assumed that radiation could reduce the cytotoxic ability of the components in F3. This decrease may occur in the degradation of curcumin compound into other compounds caused by radiation effect $[14,25]$.

\section{Antiproliferative activity test of F3 against cancer cell lines HUT78, A549, HeLa, and THP1}

Based on the fact that F3 from the irradiated sample is the most active fraction inhibiting the growth of mouse leukemia L1210 cells among the fractions, then all F3 from irradiated samples were further tested for antiproliferative activity on human cancer cell lines (lymphoma HUT78, A549 lung, cervix HeLa, and mouse leukemia THP1). The test results are presented in Fig. 4 and Table 3.

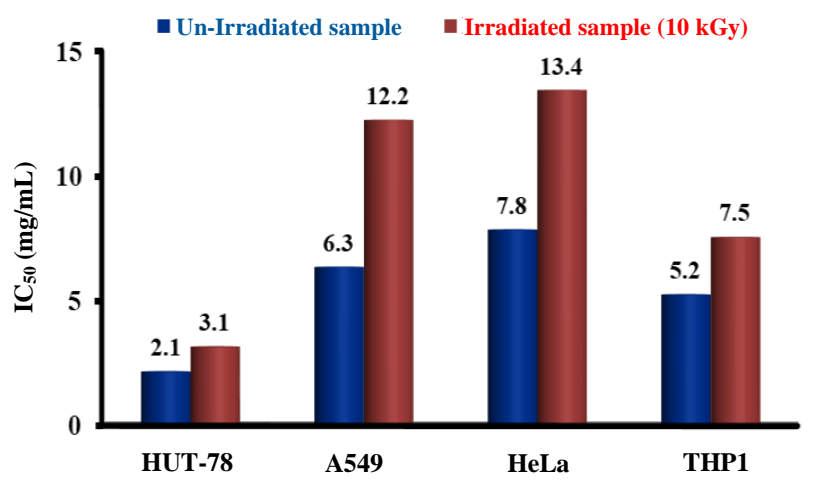

Fig. 4. $\mathrm{IC}_{50}$ value of $\mathrm{F} 3$ from ethyl acetate extract of unirradiated and irradiated samples at $10 \mathrm{kGy}$ against human cancer cell lines (HUT78, A549, HeLa, THP1).

Based on Fig. 4 and Table 3, it can be seen that radiation with a dose of $10 \mathrm{kGy}$ decreases the antiproliferative activity of F3 on lymphoma HUT78 cancer cells, A549 lung cancer cells, HeLa cervical cancer, and THP1 mouse leukemia cancer by $32 \%$, $48 \%, 42 \%$, and $31 \%$, respectively. Although the increase in $\mathrm{IC}_{50}$ value or decrease in activity is significant, the values are still in the active category, because the $\mathrm{IC}_{50}$ values are still smaller than
$20 \mu \mathrm{g} / \mathrm{mL}$. The decrease in activity caused by radiation can be overcome in two ways: first, by improving the quality of the simplicia in order to lower the initial contaminants, so as to lower the required radiation dose; and second, by increasing the concentration of simplicia in the fabrication process of herbal medicine formulation.

Table 3. Increase of $\mathrm{IC}_{50}$ value and decrease of antiproliferative activity against cancer cell lines HUT78, A549, HeLa, and THP1 of F3 from ethyl acetate fraction of unirradiated and irradiated samples at $10 \mathrm{kGy}$.

\begin{tabular}{cccccc}
\hline \multirow{2}{*}{ No } & $\begin{array}{c}\text { Cancer } \\
\text { Cell lines }\end{array}$ & \multicolumn{2}{c}{$\begin{array}{c}\mathrm{IC}_{50} \mathrm{F3}-\mathrm{EEE} * \\
(\mu \mathrm{g} / \mathrm{mL})\end{array}$} & $\begin{array}{c}\text { Increase of } \\
\text { IC }_{50} \text { value } \\
(\%)\end{array}$ & $\begin{array}{c}\text { Decrease of } \\
\text { Antiproliferative } \\
\text { Activity (\%) }\end{array}$ \\
\hline Control** & $10 \mathrm{kGy}$ & & 148 & 32 \\
1 & HUT78 & 2.1 & 3.1 & 194 & 48 \\
2 & A549 & 6.3 & 12.2 & 172 & 42 \\
3 & HeLa & 7.8 & 13.4 & 144 & 31 \\
\hline
\end{tabular}

** F3-EEE: Fraction 3 from ethyl acetate extract

$* *$ control $=$ un-irradiated sample

\section{CONCLUSION}

The maximum dose for preserving the simplicia of curcuma rhizomes with gamma irradiation is $10 \mathrm{kGy}$. Irradiation doses of up to $10 \mathrm{kGy}$ can reduce the antiproliferative activity of fraction 3 against human cancer cell lines (lymphoma HUT78 cancer cells, A549 lung cancer cells, HeLa cervical cancer cells, and THP1 mouse leukemia cancer cells). However, the reduction does not eliminate its activity. These results indicate that preservation of simplicia of curcuma rhizomes using radiation can be done at a maximum radiation dose of $10 \mathrm{kGy}$ by modifying the initial concentration of simplicia in the fabrication process of herbal medicine formulation.

\section{ACKNOWLEDGEMENT}

The authors thank all Gamma Irradiator staff members of CIRA-BATAN for irradiating the samples. A high appreciation is also addressed to Professor Bambang Pontjo Priosoeryanto, Division of Pathology, Faculty of Veterinary Medicine, Bogor Agricultural Institute, who provided laboratory facilities for in-vitro bioassay against human cancer cell lines.

\section{REFERENCES}

1. N. Aznam and S. Atun, Int. J. Green Pharm. 11 (2017) S809.

2. N.A.M. Salleh, S. Ismail and M.R. Ab Halim, Pharmacognosy Res. 8 (2016) 309. 
3. A. Nugraheni, N. Yunarto and N. Sulistyaningrum, The Indonesian Pharmaceutical Journal 5 (2015) 98. (in Indonesian)

4. E. Van Galen and B. Kroes, Assessment Report on Curcuma xanthorrhiza Roxb. (C. xanthorrhiza D. Dietrich), Rhizoma. European Medicines Agency, Science Medicines Health (2014) 1.

5. N.G. Vallianou, A. Evangelopoulos, N. Schizas et al., Anticancer Res. 35 (2015) 645.

6. Z. Udin, Indonesian Journal of Applied Chemistry 15 (2013) 23. (in Indonesian)

7. S.F. Oon, M. Nallappan, T.T. Tee et al., Cancer Cell Int. 15 (2015) 1.

8. Riki, L. Ambarsari and W. Nucholis, Indonesia Natural Research Pharmaceutical Journal 2 (2017) 1. (in Indonesian)

9. J.L. Liu, Y.Y. Pan, O. Chen et al., Oncol. Lett. 14 (2017) 5581.

10. Deepshikha, B. Kumari, E.P. Devi et al., Int. J. Agric. Environ. Biotechnol. 10 (2017) 625.

11. R. Chosdu, A Scientific Journal for the Applications of Isotopes and Radiation 4 (2008) 109.

12. E. Katrin, Susanto and H. Winarno, Indonesian Journal of Nuclear Science and Technology 15 (2014) 103. (in Indonesian)

13. R. Eriawan and S. Kusumaningrum, Molekul 10 (2015) 27. (in Indonesian)
14. E. Katrin, H. Winarno and Susanto, A Scientific Journal for the Applications of Isotopes and Radiation 7 (2011) 41. (in Indonesian)

15. E.K. Winarno, S. Fauziah, Susanto et al., A Scientific Journal for the Applications of Isotopes and Radiation 11 (2015) 137. (in Indonesian)

16. E.K. Winarno, I.R. Reswari, Susanto et al., Indonesian Journal of Nuclear Science and Technology 19 (2018) 21. (in Indonesian)

17. S.A. Fadeyi, O.O. Fadeyi, A.A. Adejumo et al., BMC Complement. Altern. Med. 13 (2013) 1.

18. E.K. Winarno, Indonesian Journal of Chemistry 12 (2012) 43.

19. E. Katrin, W. Andayani, Susanto et al., A Scientific Journal for the Applications of Isotopes and Radiation 10 (2014) 55. (in Indonesian)

20. E.A. Corcolon and M.L. Dionisio-Sese, J. Bio. \& Env. Sci. 5 (2014) 593.

21. K.N. Pushpakumari, N. Varghese and K. Kottol, Int. J. Pharm. Sci. Res. 5 (2014) 3246.

22. Á.L. Santana and M.A.A. Meireles, Food and Public Health 6 (2016) 15.

23. T.T.H. Nguyen, J. Si, C. Kang et al., Food and Chem. 214 (2017) 366.

24. Saefudin, F. Syarif and Chairul, Widyariset 17 (2014) 381. (in Indonesian)

25. N.K. Kortei, G.T. Odamtten, M. Obodai et al., Advances in Pharmaceutics 2014 (2014) 1. 